OPEN ACCESS

Edited by:

Shaili Johri,

Stanford University, United States

Reviewed by:

Antonio Calò,

University of Palermo, Italy

Sophia N. Wassermann,

University of California, Davis,

United States

*Correspondence:

Francoise Cavada-Blanco fcavada@usb.ve

Specialty section: This article was submitted to

Marine Conservation and Sustainability,

a section of the journal

Frontiers in Marine Science

Received: 22 February 2021

Accepted: 12 April 2021

Published: 13 May 2021

Citation:

Cavada-Blanco F, Cróquer A, Yerena E and Rodríguez JP (2021)

Flow of Economic Benefits From Coral Reefs in a Multi-Use Caribbean Marine Protected Area Using Network

Theory. Front. Mar. Sci. 8:671024.

doi: 10.3389/fmars.2021.671024

\section{Flow of Economic Benefits From Coral Reefs in a Multi-Use Caribbean Marine Protected Area Using Network Theory}

\author{
Francoise Cavada-Blanco ${ }^{1,2 *}$, Aldo Cróquer ${ }^{1,3}$, Edgard Yerena ${ }^{4,5}$ and Jon P. Rodríguez ${ }^{5,6,7}$ \\ 'Laboratorio de Ecología Experimental, Departamento de Estudios Ambientales, Universidad Simón Bolivar, Caracas, \\ Venezuela, ${ }^{2}$ EDGE of Existence Programme, Conservation and Policy, Zoological Society of London, London, \\ United Kingdom, ${ }^{3}$ Centro de Innovación Marina, The Nature Conservancy, Punta Cana, Dominican Republic, ${ }^{4}$ Laboratorio \\ de Areas Protegidas, Departamento de Estudios Ambientales, Universidad Simón Bolívar, Caracas, Venezuela, ${ }^{5}$ IUCN \\ Species Survival Commission, Caracas, Venezuela, ${ }^{6}$ Centro de Ecología, Instituto Venezolano de Investigaciones Científicas, \\ Altos de Pipe, Venezuela, ${ }^{7}$ Provita, Caracas, Venezuela
}

Adaptation to changes in the delivery of ecosystem services while maintaining resilience of natural systems is one of the main challenges faced by multi-use marine protected areas (MPAs). To overcome this, it is crucial to improve our understanding of interdependencies among resource users and ecosystems. In this study we used networks to model the socio-ecological system of a multi-use MPA in the southern Caribbean. Using a mixed-method approach, we built a socio ecological network (SEN) from the flow of economic benefits that stakeholders obtain from coral reefs in Los Roques National Park. We specifically looked at how these benefits are distributed among stakeholder groups and how the structure and other network properties can inform management. For this, four networks (simple, weighted, directed and directedweighted) were built from 125 nodes representing three services and six stakeholder groups, linked through 475 edges. The SEN structure indicated an open resource use pattern with reduced social capital, suggesting that community-based management could be challenging. Only $31 \%$ of the benefits from ecosystem services stay within the SEN. Regulation services, derived from the coral reef framework were the most important in terms of maintaining the flow of benefits through the SEN; however, most benefits depended on provisioning services. This approach, based on network theory allowed identification of inequalities in the access to benefits among groups, externalities in benefits derived from fisheries and trade-offs between provisioning and regulation services. Our results suggest that Los Roques might be falling into a socio-ecological trap. Improving access to benefits and increasing trust need be prioritized. Low-cost management intervention can help internalize financial benefits and reduce trade-offs affecting more vulnerable stakeholder groups. However, these would require changes in governance and institutions at the executive level.

Keywords: MPA, network, socio-ecological, fisheries, governance, tourism, coral reefs, Los Roques 


\section{INTRODUCTION}

Marine protected areas (MPAs) have been championed as a tool to increase resilience of coral reefs (Bruno and Selig, 2010; Cinner et al., 2016; Bellwood et al., 2019). Areabased protection has been put in the forefront of the global conservation agenda as a strategy to halt the loss of marine biodiversity (Toonen et al., 2013; Zhao et al., 2020). Both the Convention on Biological Diversity and the Sustainable Development Goals (SDG) set targets to protect $10 \%$ of the ocean with the goal of "safeguarding both habitats and populations of species and for delivering important ecosystem services" (CBD, 2010; Strategic Plan 2011-2020) and to "conserve and sustainably use the oceans and marine resources for sustainable development" (SDG, 2015).

However, the mere land and water coverage of a marine protected area is not indicative of its conservation value or effectiveness in moving forward toward these goals (Mora et al., 2006; Bruno and Selig, 2010). The effectiveness of MPAs to conserve biodiversity depends on a myriad of factors. While some, such as the MPA's age and size affect their protection effectiveness (Claudet et al., 2008; Edgar et al., 2014; Strain et al., 2019), those related with how the MPA is managed can ultimately hinder the area's capacity to protect biodiversity (Guidetti et al., 2008; Giakoumi et al., 2018; Strain et al., 2019). Unlike fully protected marine reserves (i.e., no-take zones), multi-use MPAs encompass areas with different levels of protection or allowed uses, often with human settlements inside the boundaries of the MPA. Here, management effectiveness becomes more critical, because securing the well-being of local communities living in, or using the MPA is also indispensable for actors to use resources sustainably and ensure the provision of ecosystem services (Mumby et al., 2014).

Recognizing where and when to adapt management and conservation interventions for resilience or transformation is becoming increasingly important to maintain the delivery of ecosystem services under a changing climate (Darling et al., 2019; Woodhead et al., 2019; Peterson St-Laurent et al., 2021). Socioeconomic and cultural processes change in response to how the provision of ecosystem services also change (Bohan et al., 2016; Bellwood et al., 2019; Williams et al., 2019). Adjustment of these processes can thus modify how resources are used by either increasing or decreasing pressure from anthropogenic local drivers of change in natural systems (Barnes et al., 2017). In multi-use coral reef MPAs where resource users are more reliant on natural resources (Cinner et al., 2011; Coulthard, 2012), changes in cultural, socioeconomic, and institutional aspects can rapidly affect the way people use these resources (Bohan et al., 2016). The relative importance that these changes have in protecting coral reefs increases within multi-use MPAs, because the effective protection of these systems is highly dependent upon limiting extractive activities for restoring and maintaining the biomass of fish and key guilds through no-take zones and fishing regulations (Bellwood et al., 2012; Mumby et al., 2014). Therefore, understanding how resource users adapt in response to changes in both the social and the ecological components of the system is key for maintaining the conservation value of these MPAs.
Using a multi-use coral reef MPA in the southern Caribbean as a study case, we explore the use of networks to understand the distribution of benefits from ecosystems among stakeholders. Socio ecological networks (SEN) can significantly aid in understanding and monitoring change in socio-ecological systems (Sayles et al., 2019; Barnes et al., 2019a). Network theory can provide information about the structure and dynamics of systems in terms of the connectivity of their components (Boccaletti et al., 2014). For more than a decade, network theory has been used as a tool to assess interactions among people and the environment (Janssen et al., 2006; Norberg and Cumming, 2008; Sayles et al., 2019). Applications in various areas of environmental and resource management demonstrate how network analysis can be useful in identifying interdependencies among people, organizations, and institutions (Bergsten et al., 2014; Alonso Roldán et al., 2015; Maciejewski and Cumming, 2015). Here, we specifically used network theory to answer the following questions: (i) how equitably distributed are benefits derived from ecosystem services among stakeholders? (ii) is the structure of the SEN likely to facilitate adaptation to change? and (iii) what components of the SEN should be prioritized when managing for change in the delivery of ecosystem services?

\section{MATERIALS AND METHODS}

\section{Governance and Management in Los Roques National Park}

Los Roques is located off the north coast of Venezuela in the southern Caribbean $\left(11^{\circ} 5^{\prime} 64^{\prime \prime} \mathrm{N}\right.$ y $\left.66^{\circ} 45^{\prime} \mathrm{W}\right)$. The MPA encompasses more than 50 coralline cays protected by two barriers within an area of 221,120 hectares (Bisbal, 2008; Figure 1). Created in 1972 Los Roques was the country's first MPA and the second of Latin America (Zamarro 2002). However, it was not until 1991, that the master plan, including specific objectives and regulations, was officially published (Gaceta Oficial, 1991). This document, known as PORU for its Spanish acronym, establishes seven categories of use ranging from notake zones to localized built areas in the islands of Gran Roque and Pirata where human settlements are allowed (Figure 1).

Los Roques has approximately 2,000 permanent residents (INE, 2014) and 60 registered lodges who operate under concessions (SATIM, 2015). Here main stakeholders are organized by trade. Community organizations include two cooperatives gathering all boaters working in tourism, one fisher's council and a tourism chamber composed mainly of lodges and dive shops. It should be noted that, the last two had not been granted official status by the government at the time of this study. As mandated by national law, there is also one general community council.

The National Park is managed by the National Parks Institute (INPARQUES), with an on-site superintendent who is responsible for drafting annual working plans, that serve as the MPA's management plan. Most fishing activities are regulated by the country's national-level fisheries authority INSOPESCA and monitored by on-site officers. In 2011, the Territorio Insular Francisco de Miranda (TIFM) was created by an executive act. 


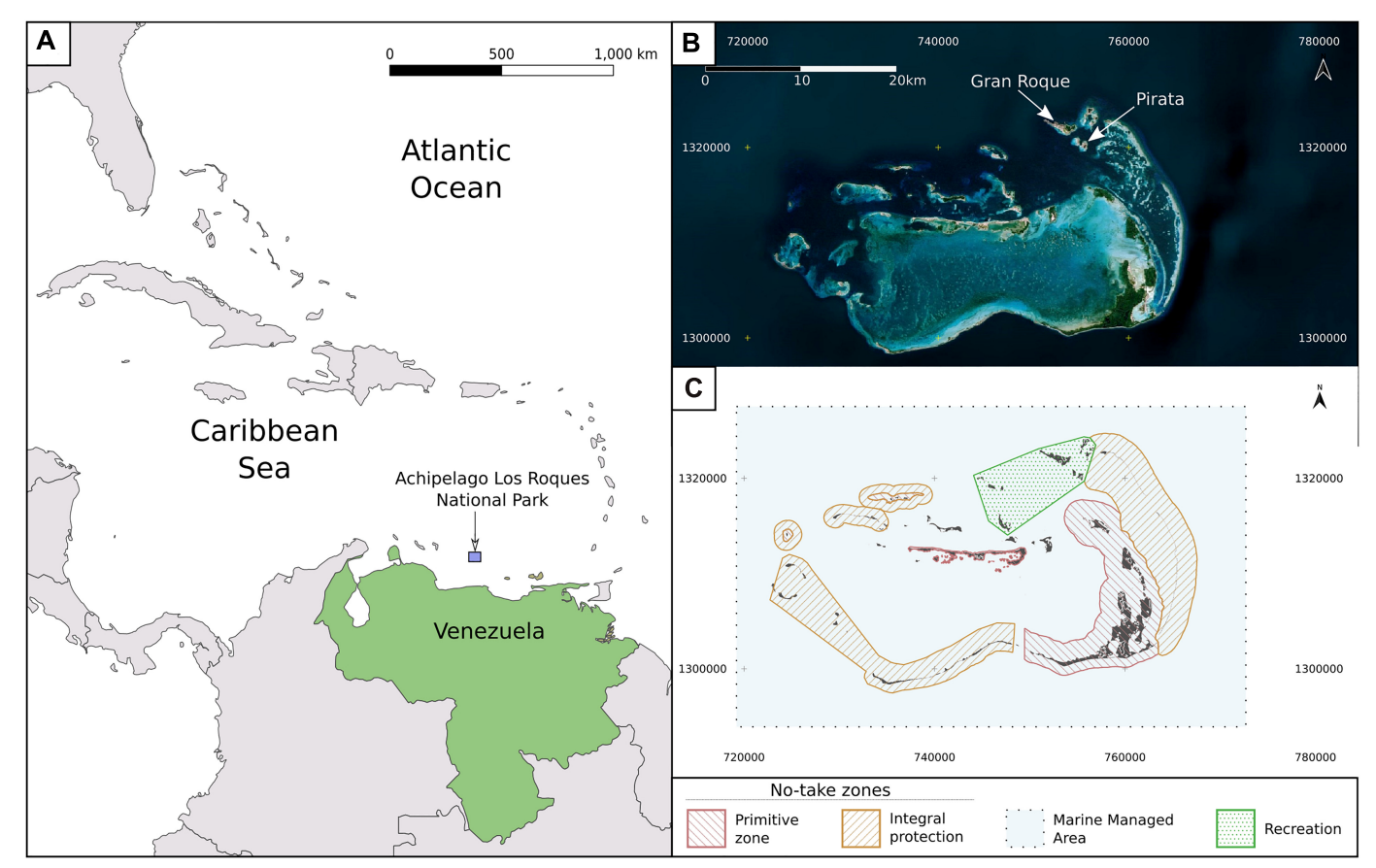

FIGURE 1 | Archipielago Los Roques National Park, a Venezuelan multi-use MPA in the southern Caribbean (A). Stellite image of the MPA is shown in panel (B), while the zoning, according to use regulations established in 1991 are shown in panel (C). Based on allowed activities the marine zones from higher to lower protection are: Integral Protection (IPZ), Primitive Area (PA), Marine Managed Area (MMA - corresponding to the extent not included in the other zones) and Recreation (RZ). Image contains modified Copernicus Sentinel data [2020], processed by ESA. Datum: EPSG: 2202 - REGVEN/UTM 19N.

The decree establishes Gran Roque, within the National Park, as its capital and grants this new "territory" attributions that collide with the country's environmental and land planning body of laws, especially pertaining those involving resource management and law enforcement in MPAs (Gaceta Oficial, 2011). Its managing director is not elected but appointed by the president and since 2013 is the de facto higher authority in the MPA.

\section{The Socio-Ecological Network}

In a network, the nodes or vertices are the components of the system and the edges or links represent the connection among them (Newman et al., 2006). We represented stakeholders and ecosystem services as nodes in our socio-ecological system. Two or more nodes were linked when they either received or passed on a benefit from any of the ecosystem services included in the network. Stakeholder's represented as nodes were selected on three criteria: (1) they benefit directly (i.e., extracted goods that are sold such as fish) or indirectly (i.e., lodges reducing costs of protein by buying fish) from coral reef's ecosystem services, (2) the economic value of such benefits could be estimated, and 3) the benefits represent their main source of income (Table 1; see Supplementary Materials for full list). Under these criteria, a total of 125 nodeswith 475 links among them were identified. We defined the system's boundaries according to the MPA extension, obtaining a partially articulated SEN (sensu Sayles et al., 2019).

Seven different stakeholder groups related with tourism or local fisheries supply chain were assigned as attributes to the nodes. Three ecosystem services were also included as attributes.
A weight was assigned to each of the network's links to build a weighted network based on the economic benefits obtained from these ecosystem services and transferred among stakeholders. Weights represent the gross benefit in US dollars that a node received either directly, or through another node. Depending on which node received and which passed on a benefit, a direction was assigned to both the simple and weighted links or edges. This directed network was used to characterize the flow of such benefits through the SEN according to the source (indegree) and target (outdegree) of the links between nodes (Figure 2).

\section{Data Collection}

To map the economic benefits obtained by stakeholders from ecosystem services in Los Roques we employed a mix-method approach (Dominguez and Hollstein, 2014). We conducted semistructured interviews in several islands of the archipelago as part of a socio-economic assessment (Cavada-Blanco, 2018), triangulating the information obtained with key informants, discussion groups and participating observation. The sampling frame was established from the list of concessions and permits granted by the MPAs' authorities. We used convenience and snowball sampling to interview a total of 161 people: 33 lodge managers (53\% of all lodges), 110 fishers (55\% of licensed fishers), the only two local fish processors in the MPA, the owners and members of staff from all three dive shops, totaling 10 people, two fish carrier captains and four board members of the two boaters' cooperatives operating in the MPA. Interview guides were slightly modified for each stakeholder group, 
TABLE 1 | Nodes within a Socio-Ecological Network (SEN) based on the flow of economic benefits derived from fisheries and tourism, the main human uses within Los Roques National Park, a multi-use MPA in the southern Caribbean.

\begin{tabular}{|c|c|c|}
\hline Nodes & Node attribute & Description \\
\hline \multirow[t]{7}{*}{ Stakeholders } & Lodges & Accommodation facilities within the MPA, ranging from 34 to 3 rooms capacity $(n=44)$ \\
\hline & Fishers & $\begin{array}{l}\text { Local fishers licensed. We used fishing boats as nodes because shares of catch among crew varied greatly } \\
\text { depending on the gear and fishing season }(n=66) \text {. }\end{array}$ \\
\hline & Fish processors & $\begin{array}{l}\text { Locally known as "tableros," these are individuals who process the fish at the landing sites and sell it to } \\
\text { lodges and residents }(n=2) \text {. }\end{array}$ \\
\hline & Lobster nurseries & $\begin{array}{l}\text { These are makeshifts nurseries kept by local fishers' families, where fishers' spiny lobster catch is kept alive } \\
\text { until the authorities make an official "weighing" and certify the catch as compliant and ready to be sold to } \\
\text { the authorized Fish carriers }(n=3) \text {. }\end{array}$ \\
\hline & Fish carriers & $\begin{array}{l}\text { Small (13-24 m LOA) trollers, longliners and decommissioned stern trawlers, which have been modified as } \\
\text { wet and freeze fish carriers. There are only six carriers authorized to buy the MPAs catch that is not locally } \\
\text { consumed }(n=2) \text {. }\end{array}$ \\
\hline & Touristic boat cooperatives & $\begin{array}{l}\text { We included the cooperatives as a node instead of individual boaters because work and payment are } \\
\text { managed by the association and most boaters are also fishers }(n=2) \text {. }\end{array}$ \\
\hline & Dive shops & $\begin{array}{l}\text { Dive shops operating daily SCUBA trips from Gran Roque. Diving sites are fixed and authorized by the } \\
\text { parks' authority }(n=3) \text {. }\end{array}$ \\
\hline \multirow[t]{3}{*}{ Services } & Provisioning (fisheries) & $\begin{array}{l}\text { Following Molberg and Folke (1999) and Mumby et al. (2014) we considered fisheries catch including the } \\
\text { yearly Caribbean spiny lobster (Panulirus argus) as a provisioning service. }\end{array}$ \\
\hline & $\begin{array}{l}\text { Regulating (Structure and coastal } \\
\text { protection) }\end{array}$ & $\begin{array}{l}\text { We mapped the following activities to the maintenance and formation of cays and beaches and wave } \\
\text { reduction: kitesurf, paddling and beaching, because > } 90 \% \text { of interviewees revealed preferences included } \\
\text { "calm water," "white sands" and "beach options provided by numerous cays." (Molberg and Folke, 1999; } \\
\text { Mumby et al., 2014; Woodhead et al., 2019) }\end{array}$ \\
\hline & Support (Biodiversity maintenance) & $\begin{array}{l}\text { We mapped SCUBA diving and snorkeling activities to the maintenance of biodiversity, for }>75 \% \text { of } \\
\text { interviewees revealed preferences included diversity of corals, fish and probability of sighting megafauna } \\
\text { (sharks, eagle rays and sea turtles) (Molberg and Folke, 1999; Mumby et al., 2014; Woodhead et al., 2019) }\end{array}$ \\
\hline
\end{tabular}
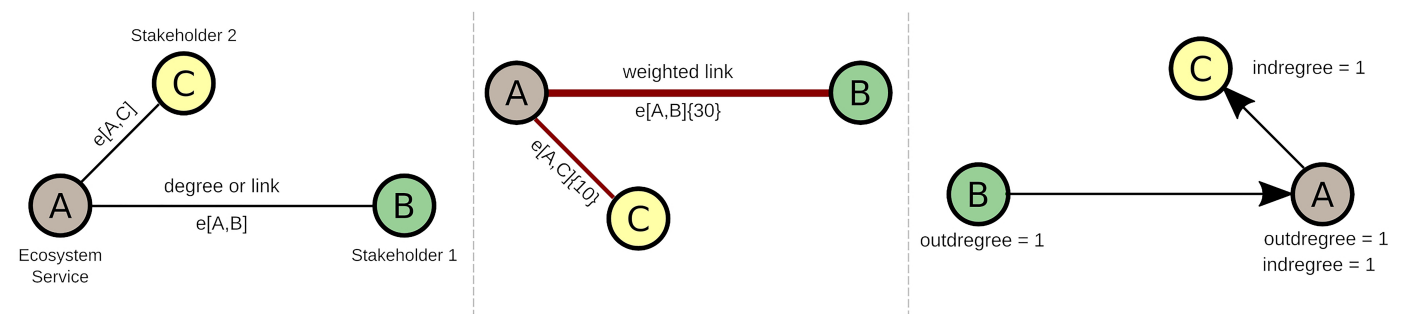

FIGURE 2 | Diagram of a minimum socio ecological network (SEN) configuration for simple, weighted and directed edges or links, where a link between two nodes is realized when each either obtains or transfers an economic benefit derived from an ecosystem service node.

but all contained a combination of closed and open-ended questions to capture quantitative and qualitative data about: (i) benefits directly and indirectly obtained from ecosystem services in the MPA, and (ii) knowledge and perception of the MPA management, resource governance and access rights (see Supplementary Materials).

As wholesale touristic packages can cause homogeneous groups of tourists to be found in the MPA for periods of weeks at a time, we designed questionnaires for tourists to be selfadministered to better capture variability among tourist groups (i.e., people from the same country and with similar income might share the same values). After piloting the questionnaire $(N=35)$ and based on response time and clarification requests, a mix of closed and open questions were included to verify data on travel cost and get information on stated and revealed preference for recreational activities (see Supplementary Materials). A total of 250 questionnaires in both Spanish and English were left on the counter of several lodges and dive shops. Questionnaires were made available to tourists between August 2014 and January 2015 (high season) and were collected twice a week by two local key informants. In total only 124 questionnaires were fully completed and collected.

We also interviewed leaders of community associations (i.e., community council, fisher's council, the local schoolteachers, local tourism chamber heads) and on-site officers from INPARQUES, the fisheries authority (INSOPESCA) and the TIFM several times to: (1) assess management structures, resource governance, and conflict resolution mechanisms (2) verify information obtained through discussion groups and observation and (3) verify how working plans and regulations are implemented. Official and ancillary data (i.e., reports, ordinances, decrees and other documents) were used to increase our understanding on, and characterize, the management and institutional context of the MPA. Semi-structured interviews 
and unstructured group discussions took place after verbal consent was granted by all interviewees and participants. During verbal consent, participants were informed about the project, its purpose, and how the data would be stored and utilized. Participant's names were not recorded, except for key informants who requested to stay anonymous when disseminating results. Information was recorded through notetaking, transcribing richqualitative data verbatim when possible. Results were presented to the community between November 2015 and February 2016 through five workshops. This project was administered by Universidad Simón Bolívar, which does not have a Review Board for research ethics regarding social science surveys.

\section{Estimation of Weights}

After evaluating all the qualitative and quantitative data obtained, we were able to only map part of the benefits derived from provisioning, support and regulation, ecosystem services related with tourism and fisheries following Molberg and Folke (1999). The gross benefit in US dollars that each node received was calculated using a combination of methods (i.e., stated market value, income factors and travel and replacement cost following Mumby et al., 2014 and Koetse et al., 2015) for direct and indirect uses. The method applied depended on the ecosystem service being valued and the stakeholder's group each node in a pair belonged to (see Table 2). This was done to avoid double counting the contribution of any given service, as many ecological processes can be involved in the delivery of two or more of such services (Van Beukering et al., 2015).

To partially control for this, we used weighted ranks when information was available to do so (i.e., on revealed preferences for activities related with tourism). When estimating the weights for benefits derived from fisheries, we allocated the same proportion of benefits to each of the ecosystem services nodes in our network. This was because the relative importance of processes responsible for the delivery of supporting and regulating ecosystem services on the provision of fish biomass is difficult to establish without site-specific information of ecological processes (Darling et al., 2017; Agudo-Adriani et al., 2019), which is not available for the study site. This approach might overestimate the economic benefits obtained by the MPA's stakeholders as it uses gross benefit for weighed links; however, it provides a good representation of the benefits obtained by stakeholders relative to each other. Therefore, allowing to investigate the structure of the SEN and the flow of such benefits. In recognition of this caveat, we present the results and discuss them in relative terms to the total economic benefits captured by our SEN.

\section{Network Analysis}

The SEN topology was assessed using a set of global metrics to better understand the structure of the system and how the benefits derived from the ecosystem services assessed above are shared among stakeholders. These metrics included the network's diameter $(d)$, density $(D)$, the average shortest path $(l)$, the average degree per node, and assortativity (Newman, 2001). These were estimated for both the simple and weighted networks. The network's density reflects the relation between the number of existing links and the maximum possible links of the network (Janssen et al., 2006). Here, it provides information about efficiency and equality in the distribution of benefits. The diameter represents the maximum shortest geodesic path between any two nodes in the network and in a general sense, it provides information about the maximum number of people connected through benefits that can be mapped to ecosystem services. We used the average shortest path to estimate the average number of intermediaries in the flow of benefits.

A nodes' degree is the number of links it has with other nodes (Newman et al., 2006), and if weighted, represents the magnitude of benefits received from the ecosystem services nodes. A high value in a node's degree provides information about the different ways in which that node receives (indegree) and passes-on (outdegree) such benefits to other stakeholders. Finally, a network's degree assortativity is a scalar value that can take values between -1 and 1 and provides information on whether nodes with similar average degrees tend to be connected to each other. A network is disassortative when nodes with higher degree are, on average, connected to nodes with lower degree and assortative when nodes with similar average degrees are, on average, connected to each other (Noldus and Van Mieghem, 2015). Here, a disassortative weighted network would suggest that most stakeholders benefited from ecosystem services through various paths and are less dependent on just a few nodes.

To answer specific questions relating to management and adaptation to change in the delivery of the services included

TABLE 2 | Description of weight estimation for edges or links between nodes within a Socio-Ecological Network (SEN) in Los Roques National Park, a multi-use MPA in the southern Caribbean. Variables used and data sources are provided in Supplementary Materials.

\begin{tabular}{|c|c|}
\hline Node pair & Edge's weight estimation \\
\hline Ecosystem services -Fishers & $\begin{array}{l}\text { Sum of total fish and lobster sold in } 2014 \text {, after adjusting each by the number of fishers in the boat and their } \\
\text { corresponding share. }\end{array}$ \\
\hline Ecosystem services - Lodges & $\begin{array}{l}\text { Structure, coastal protection and biodiversity maintenance: average gross income in } 2014 \text { based on number of } \\
\text { guests and cost of accommodation, weighted by the rank of guests' revealed preferences. Provisioning: total spent } \\
\text { in fish per Kg during } 2014 \text { multiplied by the average on-site cost per Kg of non-fish animal protein in the same period }\end{array}$ \\
\hline Ecosystem services - Dive shops & $\begin{array}{l}\text { Structure, coastal protection and biodiversity maintenance: average gross income in } 2014 \text { based on number and } \\
\text { price of dives sold, weighted by the rank of divers' revealed preferences. }\end{array}$ \\
\hline Ecosystem services - Boaters & $\begin{array}{l}\text { Structure, coastal protection and biodiversity maintenance: average gross income in } 2014 \text { based on number and } \\
\text { price of trips made, weighted by the rank of tourists' revealed preferences. }\end{array}$ \\
\hline Fish processors, carriers, and lobster nurseries & Difference between market value of fish and lobster bought and market price of fish and lobster sold in 2014. \\
\hline
\end{tabular}


in our SEN, we calculated a group of metrics for node-level properties:

\section{Key intermediaries}

We calculated the intermediation centrality of each node to identify those stakeholders that are important intermediaries in the flow of benefits through the SEN. This metric estimates the number of possible paths in which the node participates. Additionally, the SEN centrality relative to the maximum number of intermediation centrality for each node was calculated to estimate the relative importance of these nodes in the flow of benefits. These metrics were estimated in both the simple and weighted networks.

\section{Relative importance in the delivery of benefits}

To determine from which of the mapped ecosystem service stakeholders obtained the most economic benefits, we normalized the total degree weight of the weighted network by the number of degrees for each ecosystem service. To explore if this relative importance is constant across stakeholder groups, the average distance between each ecosystem service node and each stakeholder node was calculated in both the simple and weighted networks and aggregated by stakeholder group. The rate of variation in the perceived benefit, or how the perceived benefit changes as it passes from one node to the other, was also estimated as the difference between the average weighted distance from the ecosystem service per stakeholder group and the average distance in intermediary nodes.

\section{Vulnerable groups}

We assessed which stakeholder would be most affected by a reduction in the total amount of benefits perceived, relative to each of the ecosystem services included in the SEN. For this we used alpha centrality, as it considers a given value that is exogenous to the node's attributes, which is then used in estimating the importance of a node relative to those it is connected to. A node is important if it is connected to others with many links and if it has a high exogenous value (Bonacich and Lloyd, 2001). The vector of exogenous values used to estimate alpha centrality was calculated by the difference between the weighted indegrees and the weighted outdegrees, both normalized by the total number of indegrees and outdegrees per node, respectively.

To identify which components of the SEN are key for the flow of benefits among stakeholders, the articulation of each node was calculated. This provides information of which nodes in the SEN reduce connectivity when removed, disrupting the flow of benefits through the network.

\section{Cooperation among stakeholders}

According to Barnes et al. (2019b) network closure can provide information about resource and knowledge sharing among stakeholders. Therefore, the number of triangles formed within a network, is a proxy of cooperation and knowledge sharing among stakeholders (Bodin et al., 2014). For common-pool resources, such as coral-reef fisheries, this cooperation is important in facilitating their adaptation to changes (Barnes et al., 2017).
For the specific case of our networks, where links represent shared benefits from ecosystem services, network closure could facilitate a collective recognition of change in their provision. To investigate the potential for cooperation among stakeholders, we estimated the number of total triangles within the SEN and those formed by nodes with different attributes using the simple network.

Global and node-level metrics were calculated using the package igraph version 1.2.4.1 (Gabor Csardi, 2019) in $\mathrm{R}$ ( $\mathrm{R}$ Core Team, 2018). The network data is available upon request in: https://github.com/fcavada/Network_analysis_SES/ blob/main/README.md.

\section{RESULTS}

Los Roques economy is dependent on tourism and local smallscale fisheries. Lodges employ $20 \%$ of the local population, recreational activities provide income to $19 \%$ and fisheries to $18 \%$. Local fishers or "roqueños" as they called themselves, composed $75.86 \%$ of respondents, while the other $20.69 \%$ who responded to the question on whether they lived in the MPA, were those who went to Los Roques to fish during specific seasons.

There are two main fishing seasons: between April and June fishers target various species of snappers (mainly Lutjanus analis, L. griseus, L. vivanus and Ocyurus chrysurus) and almost all dedicate the period between October and the end of January to the official Caribbean spiny lobster (Panulirus argus) season, when the season is officially open (G.O $40,279,2013)$. Throughout the year, catch composition is dominated by barracuda (Sphyraena barracuda), cero mackerel (Scomberomorus regalis), jacks (Caranx hippos, C. lugubris), permit (Trachinotus falcatus), little tunny (Euthynnus alletteratus), several species of sharks (i.e., Carcharinus limbatus) and rays, mainly the spotted eagle ray (Aetobatus narinari). A more detailed description about this small-scale fishery is provided in Supplementary Materials.

In 2014, a total of 38,094 tourists traveled to the MPA, $62 \%$ of which were national tourists. According to the MPA's entrance registration record, $57 \%$ of national tourists visited on full-day packages. We obtained responses from only $4.8 \%$ of the total tourists who entered the MPA and stayed at least one night within the period questionnaires were available. Due to this, only ranked revealed activities were used from the questionnaires to map the SEN links while benefits were calculated from INPARQUES records of entries and market prices (see Supplementary Materials). Length of stay ranged between one and 15 nights, with the response's frequency mode at four nights and the lodges' capacity, calculated as number of beds, ranged between eight and 38, with most (56\%) having 16 or more. Most (40\%) of the lodges in the MPA were owned by Europeans at the time of the study, with only $6 \%$ of all lodges interviewed owned by "roqueños". All tourists who responded to the questionnaires had a university level degree and the majority of international tourists were from south America, with Brazil (11\%) and Argentina (34\%) representing the two most frequent countries of origin. Twenty three percent of 
questionnaires were responded by Venezuelans. The rest were completed by people from six different countries in North America and Europe.

\section{Network Metrics}

The gross benefit received by the SEN's stakeholders from the ecosystem services considered here totaled just over USD $\$ 52$ million with an average of USD $\$ 70,000 \pm 24,000$ received by node in 2014. The relative amount for each stakeholder ranged between $\$ 1,444.69 \pm 103.7$ year $^{-1}$ obtained by fish processors to $\$ 157,524.07 \pm 10,470$ year $^{-1}$ obtained by fish carriers (Table 3). To provide some perspective of the benefits derived from Los Roques' coral reefs, for the same year, the legal minimum salary was $\$ 645.00$ year $^{-1}$ when adjusted by the exchange rate ${ }^{1}$. However, these estimates should be analyzed in relative terms, as they do not represent net benefits. This is especially true for fish carriers whose benefit are realized once outside of the SEN.

The SEN formed one connected component (Figure 3). The average shortest path of the SEN was 2.1 (close to its diameter $d=3$ ), suggesting that most stakeholders benefit directly from the ecosystem services or through one intermediary, and that, on average, only $19.14 \%$ of the total gross economic benefits flows through the SEN. This is reflected by the SEN assortativity $((\rho=-0.64)$ and the degree distribution of the directed network. Forty eight percent of nodes had one or two indegrees (i.e., paths through which it receives benefits) and $37 \%$ had no outdegrees or paths to transfer the received benefits to other stakeholders inside the boundaries of the SEN. Based on the proportion of nodes without outdegrees, most $(80.86 \%)$ of the economic benefits derived from the ecosystem services is kept by less than half of stakeholders in the SEN, or is transferred to stakeholders outside the MPA.

\section{Key intermediaries}

The highest values for intermediation centrality on both the simple and weighted networks, corresponded to the two fish processors, followed by one of the three dive shops, and all lobster nurseries (see Supplementary Material).

\section{Relative importance in the delivery of benefits}

Regulation services provided $50.24 \%$ of the average benefits obtained by stakeholders, followed by support (25.58\%)

\footnotetext{
${ }^{1}$ Exchange rate used here is 90.95 bolivars per US dollar, estimated from the geometric mean of the monthly exchange rate accessible through the only alternatives currency market (non-government regulated).
}

TABLE 3 | Average gross economic benefit obtained by the main stakeholder's group from ecosystem services through tourism and fisheries in Los Roques National Park, a multi-use MPA in the southern Caribbean in 2014.

\begin{tabular}{lc}
\hline Stakeholder's group & Benefit in USD (average \pm standard deviation) \\
\hline Fish processors & $1,444.69 \pm 103.7$ \\
Fishers & $1,892.17 \pm 507.3$ \\
Lodges & $70,645.19 \pm 45,501$ \\
Fish carriers & $157524.07 \pm 10,470$
\end{tabular}

and provisioning (24.16\%). This importance varied among stakeholder groups (Figure 4). Accounting for both direct and indirect paths of obtaining a benefit, provisioning services provided most of the benefits obtained by fish carriers (95.3\%) and lodges (38.5\%), regulation services provided most of the benefits obtained by dive shops (43\%) and concomitantly with support services to fishers (28 and 36\%, respectively), nurseries (41 and 38.9\%, respectively) and boaters (36.8 and $47.3 \%$, respectively). The three services provided almost equal proportions of economic benefits to fish processors (Figure 4).

\section{Vulnerable groups}

The network's density $(D=0.0056)$ suggests that the flow of benefits through the SEN is not homogeneous among stakeholders. The average distance between the ecosystem service and stakeholders' nodes, indicated that the flow of benefits to fishers is direct only for provisioning services, with distance increasing on average to nearly three intermediaries for benefits coming from the support and regulation services (Table 4). Indeed, alpha centrality also suggested that fishers are the group most vulnerable to a decrease in the delivery of provisioning services (average ${ }^{\circledR}$-centrality $=0.014 \pm 0.22$ ).

Although provisioning services provided most of the benefits obtained by many stakeholders (lodges, fish carriers and directly benefiting fishers), regulation services were the most important in keeping the flow of all benefits through the SEN. This was the only node that completely disarticulated the network when its link with other nodes was removed.

\section{Cooperation among stakeholders}

In total there were 82 triangles in the SEN. Both fish carriers nodes participated in 28 triangles, the three dive shops nodes participated in 27, and a total of 12 fishers participated in 23 triangles. The other four triangles were formed by lobster nurseries and eight lodges. The number of triangles to which each node belongs indicated that connectivity among stakeholders, in terms of benefits transferred, is mediated by intermediaries. Fish carriers and dive shops were the nodes participating in most of the SEN's triangles.

\section{DISCUSSION}

\section{Equitability in the Distribution of Benefits}

As the most implemented approach in coral-reef MPAs (Maestro et al., 2019), ecosystem-based management is focused on the relationship between ecosystems and people, with management strategies aimed at securing the delivery of ecosystem service benefits (Barbier et al., 2008; Levin and Lubchenco, 2008). However, the way in which people benefit from ecosystem services depends on how they access them (Hicks and Cinner, 2014). Analysis of the directed, weighted SEN indicates that the proportion of economic benefits from the provisioning, regulation, and support services evaluated are unevenly distributed among stakeholders in Los Roques. 


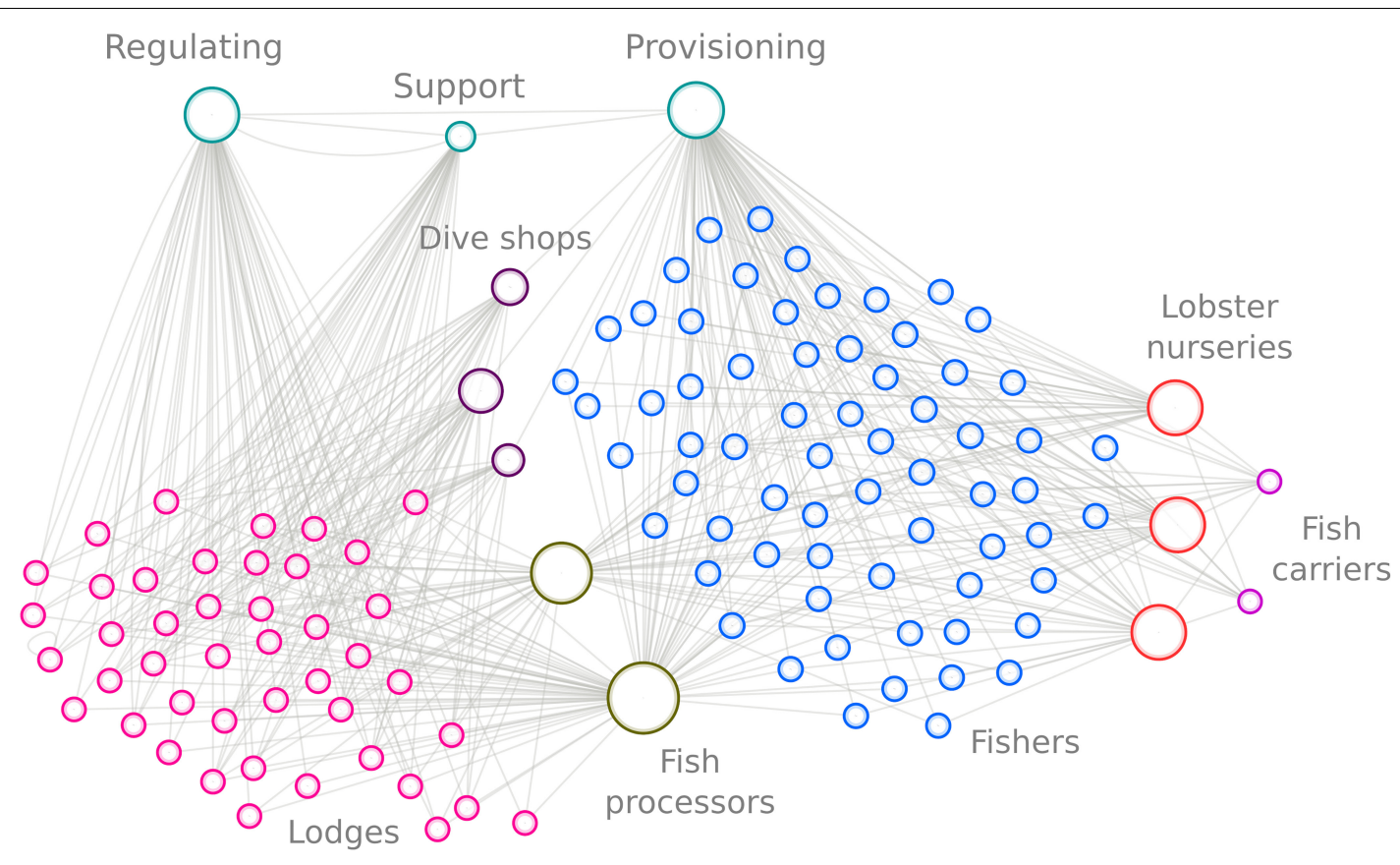

FIGURE 3 | Socio Ecological Network representing the flow of economic benefits through stakeholders in Los Roques National Park during 2014 and derived from ecosystem services through fisheries and tourism. The size of nodes represents its value of intermediation centrality.

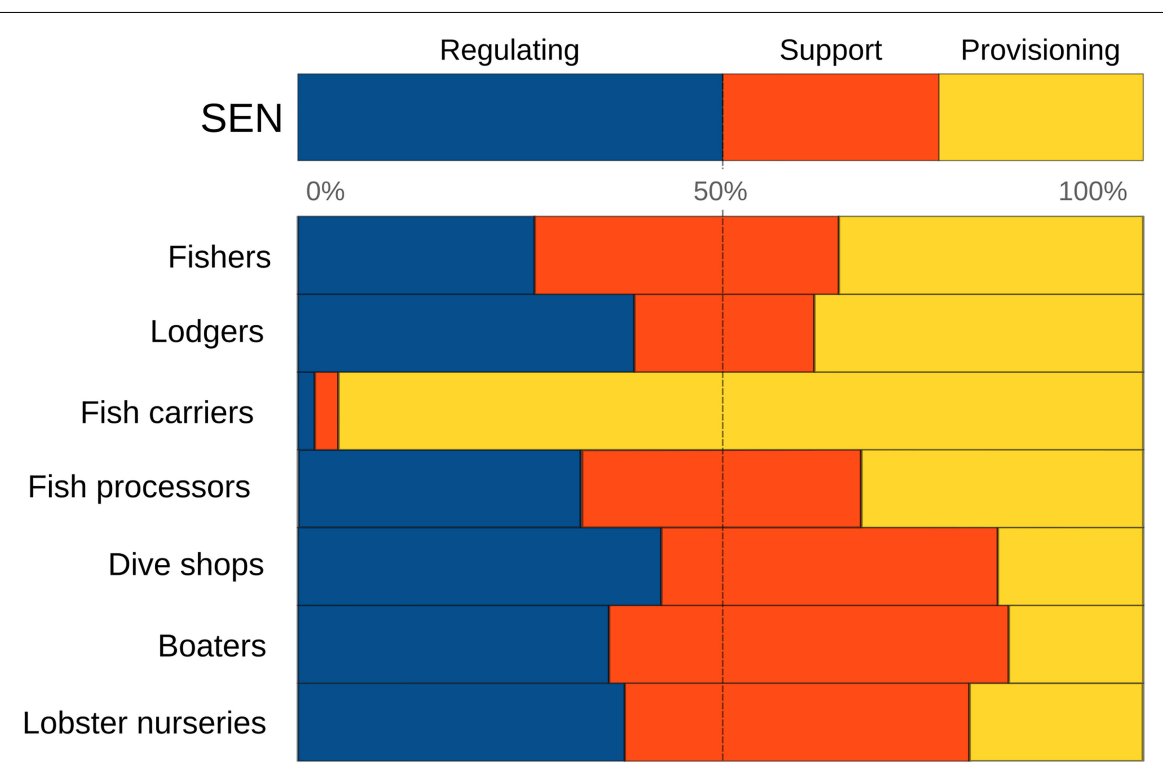

FIGURE 4 | Relative importance of the ecosystem services included within the socio ecological network (SEN) based on the amount of benefits flowing through the SEN and received by each stakeholder group.

Fish carriers and lodges obtain higher benefits from these services, benefiting the most from fisheries through indirect pathways. In contrast, fishers and fish processors are the group of stakeholders most vulnerable to a decrease in benefits from provisioning services within the MPA. Although fish carriers and lodges received the most benefit from provisioning services, their income is not directly dependent on this fishery. Fish carriers buy fish from other fisheries in the country, and lodges can transfer to customers the costs associated with substituting fish protein by alternative sources. In contrast, fishers and fish processors receive the lowest proportion of benefits from provisioning services, though their income is obtained directly from fisheries. This suggests that access mechanisms in the MPA could be causing 
TABLE 4 | Average path length ( \pm standard deviation) between each ecosystem service and stakeholder's group within Los Roques National Park's socio-ecological network (SEN).

\begin{tabular}{|c|c|c|c|c|c|c|c|}
\hline \multirow[b]{2}{*}{ Ecosystem Service } & \multicolumn{7}{|c|}{ Stakeholder group (node attribute) } \\
\hline & Lodges & Dive shops & Fishers & Fish processor & Fish Carrier & Tourism Boaters & Nurseries \\
\hline Support & $1.22 \pm 0.03$ & $2.00 \pm 0.00$ & 3.05 & $2.54 \pm 0.05$ & $2.00 \pm 0.00$ & $1.05 \pm 0.23$ & $4.62 \pm 2.11$ \\
\hline Regulating & $2.00 \pm 0.00$ & $2.00 \pm 0.00$ & $3.00 \pm 0.00$ & $2.67 \pm 0.02$ & $3.00 \pm 0.00$ & $3.015 \pm 0.81$ & $3.54 \pm 1.03$ \\
\hline Provisioning & $2.34 \pm 0.02$ & $1.00 \pm 0.00$ & $1.00 \pm 0.00$ & $2.00 \pm 0.00$ & $2.00 \pm 0.00$ & $4.21 \pm 2.05$ & $2.15 \pm 0.02$ \\
\hline
\end{tabular}

externalities among stakeholder's groups (Costanza et al., 2014; Bouma, 2015).

The steep inequality in the benefits received from provisioning services between lodges and fish carriers compared to fishers and fish processors is caused by the economic and institutional mechanisms modulating how fishers can access economic benefits from fisheries. In Los Roques, fishers' access to provisioning services is mediated by regulations that can be enforced simultaneously by different government bodies controlling fishing areas and seasons, gear types, and catch composition. These regulations have also provided fish carriers, and to a lesser degree lodges, indirect control on how fishers access provisioning services through market prices. For example, fisheries production can only leave the archipelago through a few authorized fish carriers, in the specific case of spiny lobster, once the catch is weighted and minimum allowable catch size is verified by officers from three different authorities. Lodges constitute the local market, while fish carriers are the only mean to access national markets, therefore these stakeholders' can control the economic benefits that fishers receive from fisheries. For example, in 2015 fish carriers fixed the buying price for lobster $60 \%$ below that agreed by fishers and lobster's nurseries. According to representatives from the fisher's council interviewed at the time, fishers felt obliged to sell at loss having no access to other buyers and with a shrunken local economy due to the decline in outbound tourism and the increasing economic and political crisis in the country (Parnell and Parnell, 2019). This suggest that inequality in the access to ecosystem services benefits might be driving fishers in Los Roques into a socio-ecological trap (Cinner, 2011; Barnes et al., 2017).

Fishers and fish processors are the group of stakeholders most vulnerable to a decrease in benefits from provisioning services within the MPA. Although fish carriers and lodges received the most benefit from provisioning services, their income is not directly dependent on this fishery. Fish carriers buy fish from other fisheries in the country, and lodges can transfer to customers the costs associated with substituting fish protein by alternative sources. To compensate for changes in the access to these services, fishers can seek other access mechanisms to reduce their risk (Coulthard, 2012). Most local fishers interviewed (62\%) told us they have started to sell most of their catch to fish carriers without reporting, which can be considered an illegal practice. The latter engage in transshipment as fish from the MPA was increasingly being sold to Bonaire and Aruba at higher prices and in foreign currency. To supply this demand, fishers have started to target smaller reef fish species. Fishing down these key species can create positive feedbacks through reef degradation (Mumby and Steneck, 2008) decreasing future options for adaptation to changes in the socio-ecological system driven by climate change (Cinner et al., 2018).

\section{Adaptation to Change}

The SEN's structure and closure showed that most benefits derived from ecosystem services are not shared among members of the same stakeholders' group, but instead are obtained directly as open resources (Fox et al., 2012). Due to centralized MPA access rights, rapid changes in resource governance driven by the imposition of the TIFM, have compromised common institutions and reduced social capital, which can lead to overexploitation (Basurto, 2005; Ostrom, 2009; Basurto et al., 2012).

Since 2011, when the TIFM was created, local stakeholders lost participatory and conflict resolution mechanisms, and experienced an overall loss of trust in other stakeholder groups. This has driven change in the ecological system as resource users have modified their patterns of use to reduce vulnerability (McLaughlin and Dietz, 2008). The rate at which societal and economic factors change, and the level of direct communication and trust among actors are important to achieve successful resource governance (Dietz et al., 2003; Ostrom, 2009; Folke et al., 2011). At the time we conducted interviews and informal discussions with fishers, the place where the fisher's council met, and all fishers got their supplies from, was shut down by the TIFM. Although this was presented as a temporary action, most fishers felt their ability to organize was severely affected. Discussions about relocating all landing sites and congregation points of fishers out of the main island of Gran Roque to improve the island's aesthetic undermined trust in the new authorities, and increased conflict among fishers, lodges, and boaters. A "coexistence law", put in place by the TIFM in late 2013, imposed many changes in local's daily lives within the island of Gran Roque. Simultaneously, illegal fishing by outsiders had increased with impunity and at least two people who complained publicly in community-council's assemblages were put in jail for a week. This further exacerbated the loss of social capital among stakeholders and increased conflict.

Changes in both access and constitutional rules might have decreased social capital among the different stakeholder's groups, compromising the system's resilience (Crona et al., 2011; Folke et al., 2011; Cinner et al., 2016; Pulver et al., 2018). Knowledge sharing and collective agency are more likely to happen in a SEN where links among actors sharing resources exist (Barnes et al., 2017; Dalege et al., 2017). In Los Roques SEN, fish carriers' nodes 
participated in most of the triangles formed, but only $20 \%$ of the fishers' nodes did. This configuration of the SEN could explain how Fish carriers adapted to the reduced local and national economy by supplying more lucrative near-by international markets. As they have control over how fishers' access economic benefits from fisheries and are in most the SEN triangles, fish carriers are able to better share knowledge and elicit collective action (Pelenc et al., 2013). Indeed, this "adaptation strategy" would not be possible acting alone, but with the cooperation of most fishers.

As argued by Coulthard (2012) actors can still make choices to adapt to change even if they reduce the overall resilience of the socio-ecological system. In all our informal discussions and interviews with fishers, they would acknowledge many "other" fishers were now fishing inside no-take zones and targeting parrotfishes, as carriers would only buy "white meat" fish which is "scarce outside shallow reefs except during the snapper season". Fishers treated this as a sensitive subject even though it is not illegal to catch parrotfishes in Venezuela, often acknowledging the importance of these fishes for the reef's health and adding they saw no other choice. Contrasting with lodge managers and owners, fishers had good knowledge and understanding of how reef's health is important for fisheries (Cavada-Blanco, 2018). Indeed, in the face of change, local economy can be a determinant factor in fishers' choices (Daw et al., 2012) with crisis historically increasing overexploitation and dependence on fisheries within the country (Rodríguez, 2000).

Though provisioning services was the most important of the three ecosystem services included in the SEN in terms of direct benefits, regulation services were responsible for keeping the flow of benefits among stakeholders. The shift towards smaller reef fish species in response to changes in access to benefits from provisioning services is generating a trade-off between these two services (Rodríguez et al., 2006; Brown and Mumby, 2014). Overexploitation, especially of herbivores can accelerate the degradation of coral reefs (Mumby and Steneck, 2008). However, as the benefits associated with regulation services in the SEN derive mostly from recreational activities dependent on reef framework and sanitation, a reduction in the delivery of this service will likely not affect its benefits at the pace it will those obtained from fisheries (Rogers et al., 2014; Roff et al., 2015; Kuffner et al., 2019).

This trade-off is important in maintaining future options for adaptation, as the capacity to keep reefs and other key ecosystems, such as mangroves and seagrass meadows, protected is also extremely reduced in Los Roques. Enforcement capacity has never been good in the MPA (Trujillo and Posada, 2007) and has been reduced abruptly in recent years. Previously less than ten rangers and four boats patrolled a little over 200,000 hectares of mostly open ocean, now that capacity has decreased to less than half. At the time of our interviews, INPARQUES had only three rangers on site, none of the patrol boats were in working conditions and most permanent surveillance points across the archipelago were unfit for use. Patrols had reduced from twice a month to once every three or four months excluding the southern barrier and north-west cays of the archipelago, which were too expensive to reach. The former harbors most of the
MPAs' reefs in good and excellent condition (coral cover $>40$ and $50 \%$ respectively; Cavada-Blanco et al., in revision) and potential reproductive aggregation sites for several species of groupers and snappers (Romero et al., 2011).

Low enforcement capacity seemed not to have compromised the MPAs' conservation value in the past. Los Roques is considered as one of the few healthy coral reefs in the Caribbean (Jackson et al., 2014). Abundance of key species such as parrotfishes was the highest of the region at the beginning of this century (Choat et al., 2003; Posada et al., 2003). Indeed, the MPA has several of the attributes identified as key for effective coral reef MPAs (Edgar et al., 2014): it is the oldest in the Caribbean, its area is $>100 \mathrm{Km}^{2}$, it can only be accessed by sea or air, and the effective area of human influence was small and localized. These factors have provided Los Roques high conservation value for threatened reef-building corals (Zubillaga et al., 2008; CavadaBlanco et al., in revision) and key reef species (Posada et al., 2003; Trujillo and Posada, 2007; Tavares, 2009). However, signs of reef degradation due to bleaching and coral disease epizootic events (Cróquer et al., 2003, 2005; Bastidas et al., 2012; Croquer et al., 2016), decline of reef fish species (Agudo-Adriani et al., 2019) and overexploited stocks due to damaging fishing practices (i.e., depletion of Nassau grouper's reproductive aggregations; Boomhower et al., 2010) have been reported in recent years, signaling the potential loss of its value to conserve coral reefs and key threatened marine species.

\section{Management}

The opportunity cost of reef degradation and overfishing is high for Los Roques SEN. Two thirds of stakeholders are highly dependent on provisioning services and tourism-related activities provide income to half the local residents. Moreover, market distortions created by numerous government subsidies (i.e., fuel, staple food, household electronics, boats and offboard engines) in Los Roques can increase the vulnerability and livelihood dependence (Daw et al., 2012) of not only fishers but, as shown by our SEN, also lodges and other tourism-related actors who depend on provisioning and regulation services. Internalization of externalities produced by unequal taxation and budget allocation to maintain natural capital (Bennett and Dearden, 2014) could help increase management capacity. But caution must be taken, for the methods used here overestimate the net amount of benefits accessed by stakeholders. However, estimations of value made here are below others previously made. Spalding et al. (2017) reports a value in total dollars per $\mathrm{km}^{2}$ of reef per year, considering only tourism and recreation of $>\$ 352,000$ for a third of Los Roques reef $\mathrm{area}^{2}$. That is almost the same value that the mean value per $\mathrm{km}^{2}$ estimated for all reefs in the country $(\$ 386,911)$ and is higher than those estimated for six island nations in the Caribbean (Spalding et al., 2017). Likewise, benefits from fisheries are high in Los Roques. For example, compared with Tobago, coral-reef associated fisheries in Los Roques produces three times the amount of economic benefits (Burke et al., 2008), though this is not standardized by fishing effort.

\footnotetext{
${ }^{2}$ www.oceanwealth.org
} 
As shown by the average path length of the SEN, most of the economic benefits derived from fisheries and tourism leave the MPA and there is no re-investment in maintaining the delivery of these services. Less than $1 \%$ of the total gross benefit obtained from tourism and fisheries flowing through the SEN is taxed by local authorities (SATIM, 2015). Further increasing trade-offs among fisheries and tourism, the MPA's entrance fee paid by tourists is collected by the TIFM and not the park's management body. INPARQUES' total budget for operation in 2015, excluding salaries, was $0.0001 \%$ the amount collected by entrance fees alone. Appropriately reallocating monies derived from entrance fees to the park's management body could increase the MPA's management capacity significantly and help reduce trade-offs between fisheries and tourism, even if internalization through taxation is not pursued (Ansink and Bouma, 2015) which has proved effective in other Caribbean MPAs (Hawkins et al., 2005). To realize the high potential that user fees have to generate revenue to increase and maintain management capacity of MPAs, profound institutional change at the executive level of government would be needed to stop centralization of monies taxed for ecosystem services (Kushner et al., 2012). this is widely recognized as a barrier to financial sustainability of protected areas (Depondt and Green, 2006; Emerton, 2006).

Priority should be given to rescuing, strengthening and fostering social capital. Improving stakeholder's engagement through participatory management of resources can improve compliance and reduce the need for enforcement capacity (Cinner et al., 2016; Giakoumi et al., 2018; Halik et al., 2018), helping fisher's escape the socio-ecological trap caused by restricted and unequal access to ecosystem services benefits (Hicks et al., 2009). Fish processors and dive shop staff, as highly connected nodes could be leverage points to increase the transfer of information among fishers, lodges and boaters (Barnes et al., 2019b).

Ecosystem service valuation can help increase sustainable approaches to coral reef tourism (Spalding et al., 2017; Wongthong and Harvey, 2014) to reduce its impacts on natural systems and wildlife (Trave et al., 2017). However, inequalities in the access to those benefits can exacerbate indirect drivers of biodiversity loss (Hicks and Cinner, 2014; Daw et al., 2016), something that is often overlooked (Mastrángelo et al., 2019). Network's local metrics of SENs such as those used in this case-study, could improve our understanding on the dynamics between ecosystem services availability, benefits and access mechanisms. Network theory applied in modeling socioecological systems can also help in identifying interdependencies between the social and ecological components of MPAs, improving the implementation of both, ecosystem and resiliencebased management frameworks (Bellwood et al., 2019; Mcleod et al., 2019). SENs can also be used to test the incorporation of ecosystem service valuation into management interventions, helping in lowering some of the barriers for realizing the potential of market-based strategies to protect coastal ecosystems (Balvanera et al., 2012; Vanderklift et al., 2019).

The SEN's topology and structure concomitantly with information about the management and governance context in Los Roques and the perception of stakeholders on these, show how rapid changes in governance, political allocation of resources, and inequalities can quickly decrease the conservation value accrued by an MPA for more than forty years; also reducing the capacity of its socio-ecological system to adapt to environmental change in a way that increases its resilience (Cretney, 2014; Sterk et al., 2017; Johnson et al., 2020). The SEN allowed the identification of critical interactions among components that are driving the MPA towards a socioecological trap and potential leverage points to escape such trap. Furthermore, being able to incorporate measures of benefits from ecosystem services within the SEN using data mostly recorded already by stakeholders, makes this approach useful even in MPAs with reduced management capacity. Although this is a casespecific study, its findings illustrate how site-level factors should be accounted for when setting international agreed targets for biodiversity conservation when actions to achieve such targets depend on national-level implementation.

With increased coverage of area-based protection being put in the fore of the post-Aichi biodiversity framework (Locke, 2015; Waldron et al., 2020), the site and context-specific nature of factors determining the effectiveness of management interventions in MPAs (Basurto, 2005; Ostrom, 2009; Daw et al., 2012; Cinner et al., 2016) should be considered for when setting targets. In Latin America, where centrally managed budgets cater to national priorities (Kushner et al., 2012), political allocation of resources is common (Leon, 2014) and strong government management can decrease the ability of socio-ecological systems to cope with change (Hicks et al., 2009; Brown and Mumby, 2014; Johnson et al., 2020). Adoption of appropriate management and governance indicators that incorporate interdependencies within socio-ecological systems, and provides accountability for their reporting, will be crucial to avoid area-based protection targets from driving positive feedbacks through increased inequality and poverty (Schleicher et al., 2019; IPBES, 2019).

\section{DATA AVAILABILITY STATEMENT}

The original contributions presented in the study are included in the article/Supplementary Material, further inquiries can be directed to the corresponding author/s.

\section{ETHICS STATEMENT}

Ethical review and approval was not required for the study on human participants in accordance with the local legislation and institutional requirements. The patients/participants provided their written informed consent to participate in this study.

\section{AUTHOR CONTRIBUTIONS}

FC-B conceived the study. FC-B and AC were in charge of overall planning. FC-B wrote the manuscript with support from AC, JR, and EY. JR and EY verified the results and contributed to the design of the research. All authors contributed to the article and approved the submitted version. 


\section{FUNDING}

This project was partially funded by an EDGE of Existence Fellowship awarded to Francoise Cavada-Blanco in 2013 and by the Laboratorio de Ecologia Experimental, Departamento de Estudios Ambientales, Universidad Simon Bolivar, through in-kind contributions. No funding for publication fees were received from the Fellowship grant or the author's institutions of affiliation.

\section{ACKNOWLEDGMENTS}

Field studies were authorized by the Ministerio del Poder Popular de Ecosocialismo, Habitat y Vivienda (Approval no. 0323) and Territorio Insular Francisco de Miranda (Approval

\section{REFERENCES}

Agudo-Adriani, E. A., Cappelletto, J., Cavada-Blanco, F., and Cróquer, A. (2019). Structural complexity and benthic cover explain reef-scale variability of fish assemblages in Los Roques National Park, Venezuela. Front. Mar. Sci. 6:690. doi: 10.3389/fmars.2019.00690

Alonso Roldán, V., Villasante, S., and Outeiro, L. (2015). Linking marine and terrestrial ecosystem services through governance social networks analysis in Central Patagonia (Argentina). Ecosyst. Serv. 16, 390-402. doi: 10.1016/j.ecoser. 2015.02.010

Ansink, E., and Bouma, J. A. (2015). "Payments for ecosystem services," in Ecosystem Services: From Concept to Practice, eds J. A. Bouma and P. J. H. E. van Beukering (Cambridge, MA: Cambridge University Press), 183-198.

Balvanera, P., Uriarte, M., Almeida-Leñero, L., Altesor, A., DeClerck, F., Gardner, T., et al. (2012). Ecosystem Services Research in Latin America: The State of the Art. Amsterdam: Elsevier.

Barbier, E. B., Koch, E. W., Silliman, B. R., Hacker, S. D., Wolanski, E., Primavera, J., et al. (2008). Coastal ecosystem-based management with nonlinear ecological functions and values. Science 319, 321-323. doi: 10.1126/science.1150349

Barnes, M. L., Bodin, Ö, Guerrero, A. M., McAllister, R. R. J., Alexander, S. M., and Robins, G. (2017). The social structural foundations of adaptation and transformation in social-ecological systems. Ecol. Soc. 22:16. doi: 10.5751/ES09769-220416

Barnes, M. L., Bodin, Ö, McClanahan, T. R., Kittinger, J. N., Hoey, A. S., Gaoue, O. G., et al. (2019a). Social-ecological alignment and ecological conditions in coral reefs. Nat. Commun. 10, 1-10. doi: 10.1038/s41467-01909994-1

Barnes, M. L., Mbaru, E., and Muthiga, N. (2019b). Information access and knowledge exchange in co-managed coral reef fisheries. Biol. Conserv. 238:108198. doi: 10.1016/j.biocon.2019.108198

Bastidas, C., Bone, D., Croquer, A., Debrot, D., Garcia, E., Humanes, A., et al. (2012). Massive hard coral loss after a severe bleaching event in 2010 at Los Roques, Venezuela. Rev. Biol. Trop. 60, 29-37.

Basurto, X. (2005). How locally designed access and use controls can prevent the tragedy of the commons in a Mexican small-scale fishing community. Soc. Nat. Resour. 18, 643-659. doi: 10.1080/08941920590959631

Basurto, X., Cinti, A., Bourillón, L., Rojo, M., Torre, J., and Weaver, H. H. (2012). The emergence of access controls in small-scale fishing commons: a comparative analysis of individual licenses and common property-rights in two mexican communities. Hum. Ecol. 40, 597-609. doi: 10.1007/s10745-0129508-1

Bellwood, D. R., Hoey, A. S., and Hughes, T. P. (2012). Human activity selectively impacts the ecosystem roles of parrotfishes on coral reefs. Proc. R. Soc. B Biol. Sci. 279, 1621-1629. doi: 10.1098/rspb.2011.1906

Bellwood, D. R., Pratchett, M. S., Morrison, T. H., Gurney, G. G., Hughes, T. P., Álvarez-Romero, J. G., et al. (2019). Coral reef conservation in the no. 006). We would like to acknowledge the time and good disposition provided by local MPA officers, fishers, dive shops and lodge manager, owners and staff, and local associations. The help from key informants was invaluable as well as the support of Stephanie Martinez, Esteban Agudo, and Jose Cappelletto during some of the surveys. We would also like to acknowledge Caroline Park and Claudia Gray, who proofread the manuscript and helped us improve its readability in English.

\section{SUPPLEMENTARY MATERIAL}

The Supplementary Material for this article can be found online at: https://www.frontiersin.org/articles/10.3389/fmars. 2021.671024/full\#supplementary-material

Anthropocene: confronting spatial mismatches and prioritizing functions. Biol. Conserv. 236, 604-615. doi: 10.1016/j.biocon.2019.05.056

Bennett, N. J., and Dearden, P. (2014). Why local people do not support conservation: community perceptions of marine protected area livelihood impacts, governance and management in Thailand. Mar. Policy 44, 107-116. doi: 10.1016/j.marpol.2013.08.017

Bergsten, A., Galafassi, D., and Bodin, Ö (2014). The problem of spatial fit in socialecological systems: detecting mismatches between ecological connectivity and land management in an urban region. Ecol. Soc. 19:6. doi: 10.5751/ES-06931190406

Bisbal, F. (2008). The terrestrial vertebrates of the Federal Dependences of Venezuela. Interciencia 33, 103-111.

Boccaletti, S., Bianconi, G., Criado, R., del Genio, C. I., Gómez-Gardeñes, J., Romance, M., et al. (2014). The Structure and Dynamics of Multilayer Networks. Amsterdam: Elsevier.

Bodin, Ö, Crona, B., Thyresson, M., Golz, A.-L., and Tengö, M. (2014). Conservation success as a function of good alignment of social and ecological structures and processes. Conserv. Biol. 28, 1371-1379. doi: 10.1111/cobi.12306

Bohan, D. A., Landuyt, D., Ma, A., Macfadyen, S., Martinet, V., Massol, F., et al. (2016). Networking Our Way to Better Ecosystem Service Provision. Amsterdam: Elsevier Ltd.

Bonacich, P., and Lloyd, P. (2001). Eigenvector-like measures of centrality for asymmetric relations. Soc. Netw. 23, 191-201. doi: 10.1016/S0378-8733(01) 00038-7

Boomhower, J., Romero, M., Posada, J., Kobara, S., and Heyman, W. (2010). Prediction and verification of possible reef-fish spawning aggregation sites in Los Roques Archipelago National Park, Venezuela. J. Fish Biol. 77, 822-840. doi: 10.1111/j.1095-8649.2010.02704.x

Bouma, J. A. (2015). "Local governance of ecosystems and community comanagement," in Ecosystem Services: From Concept to Practice, eds J. A. Bouma and P. J. H. E. van Beukering (Cambridge, MA: Cambridge University Press), 250-263. doi: 10.1017/cbo9781107477612.017

Brown, C. J., and Mumby, P. J. (2014). Trade-offs between fisheries and the conservation of ecosystem function are defined by management strategy. Front. Ecol. Environ. 12, 324-329. doi: 10.1890/130296

Bruno, J. F., and Selig, E. R. (2010). A global analysis of the effectiveness of marine protected areas in preventing coral loss. PLoS One 5:e9278. doi: 10.1371/journal. pone. 0009278

Burke, L., Greenhalgh, S., Prager, D., and Cooper, E. (2008). Coastal Capital: Economic Valuation of Coral Reefs in Tobago and St. Lucia. 66. Available online at: http://www.wri.org/publication/coastal-capital (accessed May 12, 2018).

Cavada-Blanco, F. (2018). Linea Base Socioecologica para la conservacion de corales amenazados en el PN Archipelago Los Roques. Caracas: Universidad Simon Bolivar. [dissertation/doctoral thesis].

CBD (2010). The Strategic Plan for Biodiversity 2011-2020 and the Aichi Biodiversity Targets. Available online at: https://www.cbd.int/sp/ (accessed October 21, 2020). 
Choat, J., Robertson, D., Ackerman, J., and Posada, J. (2003). An age-based demographic analysis of the Caribbean stoplight parrotfish Sparisoma viride. Mar. Ecol. Prog. Ser. 246, 265-277. doi: 10.3354/meps 246265

Cinner, J. E. (2011). Social-ecological traps in reef fisheries. Glob. Environ. Change 21, 835-839. doi: 10.1016/j.gloenvcha.2011.04.012

Cinner, J. E., Adger, W. N., Allison, E. H., Barnes, M. L., Brown, K., Cohen, P. J., et al. (2018). Building Adaptive Capacity to Climate Change in Tropical Coastal Communities. London: Nature Publishing Group.

Cinner, J. E., Folke, C., Daw, T., and Hicks, C. C. (2011). Responding to change: using scenarios to understand how socioeconomic factors may influence amplifying or dampening exploitation feedbacks among Tanzanian fishers. Glob. Environ. Change 21, 7-12. doi: 10.1016/j.gloenvcha.2010.09.001

Cinner, J. E., Huchery, C., MacNeil, M. A., Graham, N. A. J., McClanahan, T. R., Maina, J., et al. (2016). Bright spots among the world's coral reefs. Nature 535, 416-419. doi: 10.1038/nature18607

Claudet, J., Osenberg, C. W., Benedetti-Cecchi, L., Domenici, P., and GarcíaCharton, S. (2008). Marine reserves: size and age do matter. Ecol. Lett. 11, 481-489. doi: 10.1111/j.1461-0248.2008.01166.x

Costanza, R., de Groot, R., Sutton, P., van der Ploeg, S., Anderson, S. J., Kubiszewski, I., et al. (2014). Changes in the global value of ecosystem services. Glob. Environ. Change 26, 152-158. doi: 10.1016/j.gloenvcha.2014. 04.002

Coulthard, S. (2012). Can we be both resilient and well, and what choices do people have? incorporating agency into the resilience debate from a fisheries perspective. Ecol. Soc. 17:4. doi: 10.5751/ES-04483170104

Cretney, R. (2014). Resilience for whom? Emerging critical geographies of socioecological resilience. Geogr. Compass 8, 627-640. doi: 10.1111/gec3.12154

Crona, B. I., Ernstson, H., Prell, C., Reed, M., and Hubacek, K. (2011). “Combining social network approaches with social theories to improve understanding of natural resource governance," in Social Networks and Natural Resource Management: Uncovering the Social Fabric of Environmental Governance, eds Ö Bodin and C. Prell (New York, NY: Cambridge University Press), 44-72. doi: 10.1017/cbo9780511894985.004

Cróquer, A., Pauls, S., and Zubillaga, A. L. (2003). White plague disease outbreak in a coral reefs at Los Roques National Park, Venezuela. Rev. Biol. Trop. 51, 39-45.

Cróquer, A., Weil, E., Zubillaga, A. L., and Pauls, S. M. (2005). Impact of a white plague-II outbreak on a coral reef in the archipelago Los Roques National Park, Venezuela. Caribbean J. Sci. 41, 815-823.

Croquer, A., Cavada-Blanco, F., Zubillaga, A. L., Agudo-Adriani, E. A., and Sweet, M. (2016). Is Acropora palmata recovering? A case study in Los Roques national Park, Venezuela. PeerJ 4:e1539. doi: 10.7717/peerj.1539

Dalege, J., Borsboom, D., van Harreveld, F., and van der Maas, H. L. J. (2017). Network analysis on attitudes: a brief tutorial. Soc. Psychol. Pers. Sci. 8, 528-537. doi: 10.1177/1948550617709827

Darling, E. S., Graham, N. A., Januchowski-Hartley, F. A., Nash, K. L., Pratchett, M. S., and Wilson, S. K. (2017). Relationships between structural complexity, coral traits, and reef fish assemblages. Coral Reefs 36, 561-575.

Darling, E. S., McClanahan, T. R., Maina, J., Gurney, G. G., and Graham, N. A. J. (2019). Social-environmental drivers inform strategic management of coral reefs in the Anthropocene. Nat. Ecol. Evol. 3, 1341-1350. doi: 10.1038/s41559019-0953-8

Daw, T. M., Cinner, J. E., McClanahan, T. R., Brown, K., Stead, S. M., Graham, N. A. J. J., et al. (2012). To fish or not to fish: factors at multiple scales affecting artisanal fishers' readiness to exit a declining fishery. PLoS One 7:e31460. doi: 10.1371/journal.pone.0031460

Daw, T. M., Hicks, C. C., Brown, K., Chaigneau, T., Januchowski-Hartley, F. A., Cheung, W. W. L., et al. (2016). Elasticity in ecosystem services: exploring the variable relationship between ecosystems and human well-being. Ecol. Soc. 21:11. doi: 10.5751/ES-08173-210211

Depondt, F., and Green, E. (2006). Diving user fees and the financial sustainability of marine protected areas: opportunities and impediments. Ocean Coast. Manag. 49, 188-202. doi: 10.1016/j.ocecoaman.2006.02.003

Dietz, T., Ostrom, E., and Stern, P. C. (2003). The Struggle to Govern the Commons. Washington, DC: American Association for the Advancement of Science.

Dominguez, S., and Hollstein, B. (2014). Mixed Methods Social Networks Research. Design and Applications. New York, NY: Cambridge University Press.
Edgar, G. J., Stuart-Smith, R. D., Willis, T. J., Kininmonth, S., Baker, S. C., Banks, S., et al. (2014). Global conservation outcomes depend on marine protected areas with five key features. Nature 506, 216-220. doi: 10.1038/nature 13022

Emerton, L. (2006). Sustainable Financing of Protected Areas: A Global Review of Challenges and Options. Gland: IUCN.

Folke, C., Jansson, A., Rockström, J., Olsson, P., Carpenter, S. R., Stuart Chapin, F., et al. (2011). Reconnecting to the biosphere. Ambio 40, 719-738. doi: 10.1007/ s13280-011-0184-y

Fox, H. E., Mascia, M. B., Basurto, X., Costa, A., Glew, L., Heinemann, D., et al. (2012). Reexamining the science of marine protected areas: linking knowledge to action. Conserv. Lett. 5, 1-10. doi: 10.1111/j.1755-263X.2011.00207.x

Gabor Csardi (2019). Igraph. Available online at: https://igraph.org/r/doc/ (accessed August 8, 2019).

Gaceta Oficial (1991). Decreto 1213 Plan de Ordenamiento y Reglamento de Uso del Parque Nacional Archipielago Los Roques. Gaceta Oficial 4.250. Spain: Gaceta Oficial.

Gaceta Oficial (2011). Decreto 8549 Mediante el cual se crea el territorio Insular Francisco de Miranda. Gaceta Oficial 39.797. Spain: Gaceta Oficial.

Giakoumi, S., McGowan, J., Mills, M., Beger, M., Bustamante, R. H., Charles, A., et al. (2018). Revisiting "success" and "failure" of marine protected areas: a conservation scientist perspective. Front. Mar. Sci. 5:223. doi: 10.3389/fmars. 2018.00223

Guidetti, P., Milazzo, M., Bussotti, S., Molinari, A., Murenu, V., Pais, A., et al. (2008). Italian marine reserve effectiveness: does enforcement matter?. Biol. Conserv. 141, 699-709. doi: 10.1016/j.biocon.2007.12.013

Halik, A., Verweij, M., and Schlüter, A. (2018). How marine protected areas are governed: a cultural theory perspective. Sustainability 10:252. doi: 10.3390/ su10010252

Hawkins, J. P., Roberts, C. M., Kooistra, D., Buchan, K., and White, S. (2005). Sustainability of scuba diving tourism on coral reefs of Saba. Coast. Manag. 33, 373-387. doi: 10.1080/08920750500217518

Hicks, C. C., and Cinner, J. E. (2014). Social, institutional, and knowledge mechanisms mediate diverse Ecosystem service benefits from coral reefs. Proc. Natl. Acad. Sci. U.S.A. 111, 17791-17796. doi: 10.1073/pnas.1413473111

Hicks, C. C., McClanahan, T. R., Cinner, J. E., and Hills, J. M. (2009). Trade-offs in values assigned to ecological goods and services associated with different coral reef management strategies. Ecol. Soc. 14:10. doi: 10.5751/ES-02712-140110

INE (2014). Censos de Población Y Vivienda. Available online at: http://www.ine. gov.ve/index.php?option=com_content\&view=category\&id=95\&Itemid=26 (accessed June 19, 2014).

IPBES (2019). "Global assessment report on biodiversity and ecosystem services of the intergovernmental science-policy platform on biodiversity and ecosystem services," in IPBES Secretariat, eds E. S. Brondizio, J. Settele, S. Díaz, and H. T. Ngo (Bonn, Germany).

Jackson, J. B. C., Donovan, M. K., Cramer, K. L., and Lam, V. V. (2014). Status and Trends of Caribbean Coral Reefs. Gland: Global Coral Reef Monitoring Network, IUCN, 1970-2012.

Janssen, M. A., Schoon, M. L., Ke, W., and Börner, K. (2006). Scholarly networks on resilience, vulnerability and adaptation within the human dimensions of global environmental change. Glob. Environ. Change 16, 240-252. doi: 10.1016/ j.gloenvcha.2006.04.001

Johnson, L. R., Johnson, M. L., Aronson, M. F. J., Campbell, L. K., Carr, M. E., Clarke, M., et al. (2020). Conceptualizing social-ecological drivers of change in urban forest patches. Urban Ecosyst. [Epub ahead of print]. doi: 10.1007/ s11252-020-00977-5

Koetse, M. J., Brouwer, R., and Van Beukering, P. J. H. (2015). "Economic valuation methods for ecosystem services," in Ecosystem Services: From Concept to Practice, eds P. J. H. van Beukering and J. A. Bouma (Cambridge: Cambridge University Press), 108-131. doi: 10.1017/cbo9781107477612.009

Kuffner, I. B., Toth, L. T., Hudson, J. H., Goodwin, W. B., Stathakopoulos, A., Bartlett, L. A., et al. (2019). Improving estimates of coral reef construction and erosion with in situ measurements. Limnol. Oceanogr. 64, 2283-2294. doi: 10.1002/lno.11184

Kushner, B., Waite, R., Jungwiwattanaporn, M., and Burke, L. (2012). Influence of Coastal Economic Valuations in the Caribbean: Enabling Conditions and Lessons Learned. Washington, DC: World Resource Institute. 
Leon, G. (2014). Strategic redistribution: the political economy of populism in Latin America. Eur. J. Polit. Econ. 34, 39-51. doi: 10.1016/j.ejpoleco.2013. 12.005

Levin, S. A., and Lubchenco, J. (2008). Resilience, robustness, and marine ecosystem-based management. BioScience 58, 27-32. doi: 10.1641/B580107

Locke, H. (2015). "Nature needs (At least) half: a necessary new agenda for protected areas," in Protecting the Wild: Parks and Wilderness the Foundation for Conservation, eds E. Crist, G. Wuerthner, and T. Butler (Washington, DC: Island Press-Center for Resource Economics), 5-15.

Maciejewski, K., and Cumming, G. S. (2015). The relevance of socioeconomic interactions for the resilience of protected area networks. Ecosphere 6:art145. doi: 10.1890/ES15-00022.1

Maestro, M., Pérez-Cayeiro, M. L., Chica-Ruiz, J. A., and Reyes, H. (2019). Marine protected areas in the 21st century: current situation and trends. Ocean Coast. Manag. 171, 28-36. doi: 10.1016/j.ocecoaman.2019. 01.008

Mastrángelo, M. E., Pérez-Harguindeguy, N., Enrico, L., Bennett, E., Lavorel, S., Cumming, G. S., et al. (2019). Key knowledge gaps to achieve global sustainability goals. Nat. Sustain. 2, 1115-1121.

McLaughlin, P., and Dietz, T. (2008). Structure, agency and environment: toward an integrated perspective on vulnerability. Glob. Environ. Change 18, 99-111. doi: 10.1016/j.gloenvcha.2007.05.003

Mcleod, E., Anthony, K. R. N., Mumby, P. J., Maynard, J., Beeden, R., Graham, N. A. J., et al. (2019). The Future of Resilience-Based Management in Coral Reef Ecosystems. Cambridge, MA: Academic Press.

Molberg, F., and Folke, C. (1999). Ecological goods and services of coral reef ecosystem. Ecol. Econ. 29, 215-233. doi: 10.1016/s0921-8009(99)00009-9

Mora, C., Andréfouët, S., Costello, M. J., Kranenburg, C., Rollo, A., Veron, J., et al. (2006). Coral reef and global network of MPA. Science 312, 1750-1751.

Mumby, P. J., Flower, J., Chollett, I., Box, S. J., Bozec, Y. M., Fitzsimmons, C., et al. (2014). Towards Reef Resilience and Sustainable Livelihoods: A handbook for Caribbean coral reef managers. Exeter: University of Exeter.

Mumby, P. J., and Steneck, R. S. (2008). Coral Reef Management and Conservation in Light of Rapidly Evolving Ecological Paradigms. Amsterdam: Elsevier.

Newman, M., Barabási, A.-L., and Watts, D. J. (2006). The Structure and Dynamics of Networks. Princeton, NJ: Princeton University Press.

Newman, M. E. J. (2001). Scientific collaboration networks. II. Shortest paths, weighted networks, and centrality. Phys. Rev. E Stat. Phys. Plasmas Fluids Relat. Interdiscip. Top. 64:e016132. doi: 10.1103/PhysRevE.64.016132

Noldus, R., and Van Mieghem, P. (2015). Assortativity in complex networks. J. Complex Netw. 3, 507-542. doi: 10.1093/comnet/cnv005

Norberg, J., and Cumming, G. (2008). Complexity Theory for a Sustainable Future. Columbia University Press.

Ostrom, E. (2009). A general framework for analyzing sustainability of socialecological systems. Science 325, 419-422. doi: 10.1126/science.1172133

Parnell, J. A., and Parnell, J. A. (eds) (2019). "Nonmarket strategy in venezuela," in Nonmarket Strategy in Business Organizations (Berlin: Springer International Publishing), 87-97. doi: 10.1007/978-3-319-93242-2_8

Pelenc, J., Lompo, M. K., Ballet, J., and Dubois, J. L. (2013). Sustainable human development and the capability approach: integrating environment, responsibility and collective agency. J. Hum. Dev. Capabilit. 14, 77-94. doi: 10.1080/19452829.2012.747491

Peterson St-Laurent, G., Oakes, L. E., Cross, M., and Hagerman, S. (2021). R-R-T (resistance-resilience-transformation) typology reveals differential conservation approaches across ecosystems and time. Commun. Biol. 4, 1-9. doi: 10.1038/s42003-020-01556-2

Posada, J. M., Villamizar, E., and Alvarado, D. (2003). Rapid Assessment of Coral Reefs in the Archipelago de Los Roques national park, Venezuela (PART 2 : FISHES). Agra: AGRRA.

Pulver, S., Ulibarri, N., Sobocinski, K. L., Alexander, S. M., Johnson, M. L., and Mccord, P. F. (2018). Frontiers in socio-environmental research: components, connections, scale and context. Ecol. Soc. 23:23.

R Core Team (2018). R: A Language and Environment for Statistical Computing. Vienna: R Foundation for Statistical Computing.

Rodríguez, J. P. (2000). Impact of the Venezuelan economic crisis on wild populations of animals and plants. Biol. Conserv. 96, 151-159. doi: 10.1016/ S0006-3207(00)00061-6
Rodríguez, J. P., Beard, T. D., Bennett, E. M. Jr., Cumming, G. S., Cork, S. J., Agard, J., et al. (2006). Trade-offs across space, time, and ecosystem services. Ecol. Soc. $11: 28$.

Roff, G., Zhao, J., and Mumby, P. J. (2015). Decadal-scale rates of reef erosion following El Niño-related mass coral mortality. Glob. Change Biol. 21, 44154424. doi: $10.1111 / \mathrm{gcb} .13006$

Rogers, A., Blanchard, J. L., and Mumby, P. J. (2014). Vulnerability of coral reef fisheries to a loss of structural complexity. Curr. Biol. 24, 1000-1005. doi: 10.1016/j.cub.2014.03.026

Romero, M., Judson, B., Posada, J. M., and William, D. (2011). Identificacion de sitios de agregaciones de desove de peces a traves del conocimiento ecologico local de pescadores en el Parque Nacional Los Roques, Venezuela. Interciencia $36,88-95$.

SATIM (2015). Rendicion de Cuentas 2015. Caracas: Servicio de Administracion Tributaria Territorio Insular Miranda.

Sayles, J. S., Mancilla Garcia, M., Hamilton, M., Alexander, S. M., Baggio, J. A., Fischer, A. P., et al. (2019). Social-Ecological Network Analysis for Sustainability Sciences: A Systematic Review and Innovative Research Agenda for the Future. Bristol: Institute of Physics Publishing.

Schleicher, J., Zaehringer, J. G., Fastré, C., Vira, B., Visconti, P., and Sandbrook, C. (2019). Protecting half of the planet could directly affect over one billion people. Nat. Sustain. 2, 1094-1096. doi: 10.1038/s41893-0190423-y

SDG (2015). Transforming Our World: The 2030 Agenda for Sustainable Development. London: United Nations.

Spalding, M., Burke, L., Wood, S. A., Ashpole, J., Hutchison, J., and zu Ermgassen, P. (2017). Mapping the global value and distribution of coral reef tourism. Mar. Policy 82, 104-113. doi: 10.1016/j.marpol.2017. 05.014

Sterk, M., van de Leemput, I. A., and Peeters, E. T. (2017). How to Conceptualize and Operationalize Resilience in Socio-Ecological Systems?. Amsterdam: Elsevier.

Strain, E. M. A., Edgar, G. J., Ceccarelli, D., Stuart-Smith, R. D., Hosack, G. R., and Thomson, R. J. (2019). A global assessment of the direct and indirect benefits of marine protected areas for coral reef conservation. Divers. Distrib. 25, 9-20. doi: $10.1111 /$ ddi. 12838

Tavares, R. (2009). Análisis de Abundancia, Distribución y Tallas de Tiburones Capturados Por Pesca Artesanal en el Parque Nacional Archipiélago los Roques, Venezuela. Interciencia 34. Available online at: http://ve.scielo.org/scielo. php?pid=S0378-18442009000700005\&script=sci_arttext\&tlng=en (accessed November 19, 2019).

Toonen, R. J., Wilhelm, T. A., Maxwell, S. M., Wagner, D., Bowen, B. W., Sheppard, C. R. C., et al. (2013). One size does not fit all: the emerging frontier in largescale marine conservation. Mar. Pollut. Bull. 77, 7-10. doi: 10.1016/j.marpolbul. 2013.10.039

Trave, C., Brunnschweiler, J., Sheaves, M., Diedrich, A., and Barnett, A. (2017). Are We Killing Them With Kindness? Evaluation of Sustainable Marine Wildlife Tourism. Amsterdam: Elsevier.

Trujillo, W., and Posada, J. M. (2007). La Pesquería de Langosta (Panulirus argus) en el Parque Nacional Archipiélago los Roques: Temporadas 2004-2005 y 2005-2006. London: Gulf and Caribbean Fisheries Institute, 182-187.

Van Beukering, P. J. H., Brouwer, R., and Koetse, M. J. (2015). "Economic values of ecosystem services," in Ecosystem Services: From Concept to Practice, eds P. J. H. van Beukering, and J. A. Bouma (Cambridge, MA: Cambridge University Press), 89-107. doi: 10.1017/cbo9781107477612.008

Vanderklift, M. A., Marcos-Martinez, R., Butler, J. R. A., Coleman, M., Lawrence, A., Prislan, H., et al. (2019). Constraints and opportunities for market-based finance for the restoration and protection of blue carbon ecosystems. Mar. Policy 107:103429. doi: 10.1016/j.marpol.2019.02.001

Waldron, A., Adams, M., Allan, J., Arnell, A., Asner, G., Atkinson, S., et al. (2020). Protecting 30\% of the Planet for Nature: Costs. Benefits and Economic Implications (Campaign for Nature). Available online at: https://www.conservation.cam.ac.uk/files/waldron_report_30_by_30_publish (accessed January 21, 2021).

Williams, G. J., Graham, N. A. J., Jouffray, J. B., Norström, A. V., Nyström, M., Gove, J. M., et al. (2019). Coral reef ecology in the Anthropocene. Funct. Ecol. 33, 1014-1022. doi: 10.1111/1365-2435.13290

Wongthong, P., and Harvey, N. (2014). Integrated coastal management and sustainable tourism: a case study of the reef-based SCUBA dive industry from 
Thailand. Ocean Coast. Manag. 95, 138-146. doi: 10.1016/j.ocecoaman.2014. 04.004

Woodhead, A. J., Hicks, C. C., Norström, A. V., Williams, G. J., and Graham, N. A. J. (2019). Coral reef ecosystem services in the Anthropocene. Funct. Ecol. 33, 1023-1034. doi: 10.1111/1365-2435. 13331

Zamarro (2002). Guía del parque Nacional Archipiélago Los Roques. Spain: Agencia de Cooperacion Espanola-MARNNR.

Zhao, Q., Stephenson, F., Lundquist, C., Kaschner, K., Jayathilake, D., and Costello, M. J. (2020). Where marine protected areas would best represent $30 \%$ of ocean biodiversity. Biol. Conserv. 244:108536. doi: 10.1016/j.biocon.2020. 108536

Zubillaga, A. L., Márquez, L. M., Cróquer, A., and Bastidas, C. (2008). Ecological and genetic data indicate recovery of the endangered coral Acropora palmata in
Los Roques, Southern Caribbean. Coral Reefs 27, 63-72. doi: 10.1007/s00338007-0291- 1

Conflict of Interest: The authors declare that the research was conducted in the absence of any commercial or financial relationships that could be construed as a potential conflict of interest.

Copyright (C) 2021 Cavada-Blanco, Cróquer, Yerena and Rodríguez. This is an openaccess article distributed under the terms of the Creative Commons Attribution License (CC BY). The use, distribution or reproduction in other forums is permitted, provided the original author(s) and the copyright owner(s) are credited and that the original publication in this journal is cited, in accordance with accepted academic practice. No use, distribution or reproduction is permitted which does not comply with these terms. 